\title{
Ethics of Wisdom and Compassion in the Novels by Chitra Banerjee Divakaruni
}

\author{
Metka ZUPANČIČ
}

\begin{abstract}
In a variety of her writings, Indian-born Chitra Banerjee Divakaruni who currently resides in Houston, Texas, provides new perspectives to contemporary women's literature in the United States. Positioned at the interface of various cultures, Divakaruni draws from her Bengali heritage to combine history, myth and magic, together with the respect for diversity that underscores ethics as the foundation of human interactions. Among Divakaruni's novels, The Mistress of Spices, The Palace of Illusions, The Brotherhood of the Conch trilogy and One Amazing Thing all propose new paradigms of wisdom and compassion that may bring about a better understanding among all.
\end{abstract}

Keywords: Chitra Banerjee Divakaruni, rewriting of Indian tradition, ethics, wisdom, compassion

\section{Izvleček}

V Indiji rojena pisateljica Chitra Banerjee Divakaruni, ki zdaj deluje v Houstonu, s svojimi številnimi literarnimi dosežki prinaša nove razsežnosti $\mathrm{v}$ sodobno ameriško žensko književnost. Na križpotju med številnimi kulturami se Divakaruni naslanja predvsem na svojo izvirno bengalsko tradicijo in povezuje zgodovino, mitologijo in magijo s posebnim spoštovanjem do različnosti, kar nujno vodi do etike kot temeljne vrednote v medčloveških odnosih. V romanih, kot so The Mistress of Spices, The Palace of Illusions, trilogija The Brotherhood of the Conch in One Amazing Thing, avtorica razvija nove paradigme modrosti in sočutja, ki naj doprinesejo k boljšemu medsebojnemu razumevanju.

Ključne besede: Chitra Banerjee Divakaruni, sodobno preoblikovanje indijske tradicije, etika, modrost, sočutje

\footnotetext{
* Metka Zupančič, Professor of French-Modern Languages, Department of Modern Languages and Classics, University of Alabama at Tuscaloosa, United States.

mzupanci833@gmail.com
} 
Indian-born Chitra Banerjee Divakaruni brought new perspectives to contemporary women's writings in the United States with a series of highly praised novels and short stories, after she was first honoured as a poet. Positioned at the interface of various cultures - originally from Kolkata and now residing in Houston, Texas-Divakaruni is herself the embodiment of the themes prevalent in her writings, or, as she states on her personal website, those of "women, immigration, the South Asian experience, history, myth, magic and celebrating diversity." Her literature allows for a variety of readings such as Feminism, Transnationalism and Multiculturalism, with notions of exile, postcolonialism, and hybridity mixing with myth and magic situated at the very core of Divakaruni's numerous narratives that would not exist without these dimensions. While most of Western researchers of Divakaruni's works tend to privilege the new global dimensions in Divakaruni's work such as they appeal to contemporary criticism, the spiritual aspects based on the writer's Indian heritage continue to be somewhat obfuscated, foreign, hard to embrace and difficult to grasp, especially when dealt with in academic settings.

Chitra Divakaruni's originality, literary value and her importance for posterity nevertheless rise above the mere connection to her heritage and to the issues pertaining to (South Asian) women living in a new environment. Rather, Divakaruni's literature represents a daring yet also smooth and spontaneous interaction between various worlds and ways of existence, those considered as "real" and those considered as "supernatural" or "imaginary." In this intersection of possible existences, of ways of being - that do not contradict one another but appear to be particularly complementary, her vivid, engaging style strongly supports the literary personae that fully lead their complex novelistic life. The coexistence of "magical fantasy" (as described in her various interviews) and the characteristics of hybrid, postcolonial or postmodern, novelistic devices in this prose have often lead the author to define her writing approach as magical realism. As stated by Gita Rajan "Divakaruni uses mysticism to achieve her goal of making the commonplace wondrous and the real extra-ordinary" (Rajan 2002, 216).

When speaking of "magical" or "mystical" realism, Divakaruni's three volumes written for "children" (or rather for readers of all ages), The Brotherhood of the Conch (2003, 2005 and 2009b), are certainly to be considered, together with her two influential novels, The Mistress of Spices (1997) and The Palace of Illusions (2008b). Nevertheless, one can easily posit that in her stories and novels, everything (the "magical" included) is "real," convincing and natural. There is a 
constant interaction of worlds and interpenetration of various levels of human existence, so that Divakaruni's other texts, although apparently set closer to everyday "reality," also suggest a deep emotional and spiritual connection that each character nourishes with "other" dimensions. Without such a connection, life might become rather unbearable for characters in the novels such as Sister of my Heart (1999) and its sequel The Vine of Desire (2002b), but also Queen of Dreams (2004) and in particular Divakaruni's latest novel, One Amazing Thing (2009a). These dimensions may most often be described as "cosmic," global, and definitely transpersonal.

In today's world ruled by self-absorbed individuals, with egotistic preoccupations that foster divisions, conflicts and separations, Divakaruni's depiction of deep, albeit often unseen connections, with interdependence and necessary reliance upon the most honourable features in ourselves, is not just refreshing but a powerful reminder of a potential that humanity needs to uncover at the earliest to avoid more crises and catastrophes. In this sense, Divakaruni's prose writings, especially some of the more recent ones, carry profound ethical values and the promise of a world that we could all build together, with literature as an efficient and convincing tool for collective transformation based on mutual understanding and love as a binding force that may perform miracles. In other words, as Divakaruni insisted upon during her AtGoogle talk in February 2010, as well as during our interview conducted in July 2010: in times of panic and disasters, we need to be aware that we are a community. Our concern for others and not just for ourselves should guide us, as she suggested "We want to survive, but not at the cost of losing our humanity" (AtGoogle talk).

Chitra Divakaruni patiently constructed such a worldview through many years of astute observations, together with the remembrance of traditional teachings that she received from her Bengali community and family; she often mentions the influence of her grandfather's storytelling as the biggest stimulus for the reactivation of her own memories, through her own literature. She is thus capable of bringing together her scholarship and high literary standards, in order to generously offer her own wisdom and compassion in her writing, with her understanding of the past that is intrinsically connected to the future on this earth.

Chitra Banerjee Divakaruni's literature brings about a fine synthesis, a new version of how in the past decades, the (often stereotypical) representations of East (in Western culture) have been transformed and adapted to the needs of rapidly changing circumstances, both in literature and in everyday life. With a vision, 
inner poise, and an open heart and mind, this writer has secured herself a position in today's world literature as a woman who not only knows how to tell stories but also how to make us enter into them fully, inhabiting them together with her. In this regard, she is a magician who understands how to trigger the innermost reaction in her readers, so that we become permeable to the new paradigms she is laying out for us. At the same time, her novels may also be seen as laboratories where new ways of human coexistence are being tested.

The energies Divakaruni deploys and examines through her characters are quite often still not perceived in their fullness, especially by those who may not have been exposed to - or have not reflected upon - the dimensions she continues to tackle in her writings. They may not have experienced, or tried to understand, the paradigms she works with, at the level she has done so far. Her literature may certainly be appreciated by a large readership from extremely various walks of life and cultural backgrounds; experience also shows that some of the finest ideas articulated in this prose remain hidden or at least foreign even to (more sensitive Western) students of literature.

The existing scholarship (see for example Susan Mollar Okin, 2002) shows quite clearly that a variety of readings that combine contemporary theories of exile and hybridity can be applied to The Mistress of Spices in a productive and legitimate way. These mostly "reality based" and rationally configured approaches may nevertheless not account for the vast spiritual foundations of this particular novel, with the presence of myth and magic that defines the narrative (Rajan 2002). In working on this novel with students in an advanced seminar on critical theory, the question that could not be adequately asked — let alone answered — had to do with the importance of symbols that originated from Indian epics and from a tradition that views the world differently from Westerners. Regardless of the opportunities offered by electronic search engines, myths and symbols from the Indian subcontinent are not yet systemized appropriately and are not easily found. To be more fully understood in their initial context, they also require a much vaster familiarity with comparative and world literature, which is seldom the case in today's academia.

A number of major issues seem to be of a particular interest in The Mistress of Spices if we want to read the novel from a larger spiritual perspective that may draw on Post-Jungian analytical psychology, an approach that (still) does not compete well for its place in today's academia. At the center of this novel of Divakaruni, we witness an uncanny encounter in Oakland, California, between an 
Indian "mistress of spices," a young woman hidden in the disguise of an old recluse, Tilo, and a socially successful descendant of the First Nations, Raven. In the Jungian sense of the conjunction of the opposites, the novel thus plays with the binaries that do not preclude one another. Tilo chose to be magically transported to Oakland in order to help her own community; she has to abide by a number of strict rules, remain hidden and non-assuming. But circumstances push her on the path of identity quest that can only be accomplished if she accepts the possibility of her own change as she is recognized beyond the outer appearance for her deepest nature. The same goes for the male character, Raven, who needs to open up and accept his heritage, starting with his own identification with the mythical figure of a raven that holds numerous connotations in both Indian and Native American culture.

In a way, Divakaruni's imaginary constructs take into consideration the remote possibilities of cross-pollination between Asian and North American symbolism. She also tackles another major notion, the interpenetration of the individual and the collective. In other words, the ethical dimensions are quite overtly examined in Divakaruni's novels: how a personal fate, karma, affects the events on the scale of a major earthquake, which will lead to a necessary shift in perception and to a major transformation of all those involved in the process. Here again, a cyclical view of time suggests periods of apparent calm that are followed by life-changing destructions. The perception that we always progress in circles or rather in spirals, under the influence of more or less balanced forces, takes us back to the Eastern experience of human existence. Lastly, with a major shifting of the earth (during an earthquake) placed at the end of The Mistress of Spices, which corresponds to a symbolic shifting of how life is to be understood, the writer positions Tilo and her spices at the center of the interaction between races and cultures, even various Indian cultures, with people of all ages, prejudices, and expectations. This narrative situation offers almost a direct link with Divakaruni's latest published volume, One Amazing Thing, where a group of strangers is confined to a common place because of an earthquake that forces them to explore who they are and what they expect of life. As also underscored by Divakaruni in various interviews (for example during the AtGoogle Talks on February 10, 2010), in this novel, there is no single main character and "all that is going on is equally important." Thus, the writer is creating a new paradigm of a network, of horizontal connections, of the necessary interaction and mutual respect, with no vertical, hierarchical laws, but rather with a process at the core level, of interdependence that is based on the recognition of other people's equally important suffering and inner secrets. 
Before publishing One Amazing Thing, the writer, as the extradiegetical authority, may have been the one who narrated the stories of others and organized them in her books, with an insight into her characters' thoughts and emotions. In this novel, though, she allows for the nine equally important narrators to meet and combine their energies: they all agree to tell a story that they would not have revealed under any other circumstances. As Boccaccio in the Decameron, or later Marguerite de Navarre in her Heptameron, and, by Divakaruni's avowal, Ann Patchett in her Bel Canto (AtGoogle, February 10, 2010), our writer understands the immense power of storytelling, in a situation when people, as she states, are "surviving under very difficult circumstances" (AtGoogle, February 10, 2010).

Circumstances are never very easy in any of Divakaruni's novels or stories. By showing the inner strength and the resourcefulness of her characters, the writer is providing options and models for her readers. This is particularly obvious in her retelling of the most sacred Indian epic, Mahābhārata, with the significant title The Palace of Illusions (2008b). The title itself serves as a general metaphor for life as "Maya," an illusion that we humans continue to sustain with such efforts and pains, through conflicts, meanness, humiliation, overpowering, while we certainly lack understanding about the laws that govern our lives without our knowledge, or a major possibility to influence their nature. This novel positions its readers even more completely in a world that is old and new, magical and real at the same time. The major novelty brought by Divakaruni lies in the fact that the story is focused on the legendary woman named Draupadi or Panchaali (the name more often used in the novel), who right from the beginning received the prophecy that her life was to change the course of history. How to sustain such a burden when a person is socially destined to be in a subordinate position? How was she to find her own identity when fate decided that she would become a wife of five brothers, five paradigms of male supremacy, rather, five subpersonalities (in the language of Roberto Assagioli) of a whole that cannot be divided if the strength is to be maintained and the challenges met? In a way, Panchaali's task is to develop multiple qualities that will allow her to live as harmoniously as possible not just with the five men, in a cyclical arrangement that brings each of them to her bed once in five years, but also with the rest of the society she is exposed to. Born out of fire, she lives at the peak of her glory in a palace made of water, in the midst of a desert: all elements meet to sustain this unusual heroine to whom the ancients may not have given a major role in the epic, because the system during which the verses have been progressively put together has already relegated women to a secondary position. If we are to believe a possibility that in the Vedic times, 
goddess were "portrayed as creatrices of the universe" (see Ditrich 2008, 162), we may posit that Panchaali, in her uniqueness as perceived by Divakaruni, draws her energy from the older female deities whose role has later been forgotten, while she also prefigures a time when even in India, women will have much larger social and spiritual functions. In Divakaruni's novel, Panchaali is continuously forced to recreate her own universe and to learn from her mistakes, her hubris, and mainly from her deep yearning, never avowed, for yet another man whom for social reasons she could not have accepted in her youth.

Divakaruni's daring literary adventure certainly consists in the reenacting, from a woman's perspective, of the old conflicts inscribed in a five thousand page "original," told and retold for thousands of years, translated and transformed, but where the basic human problems remain the same: how desire and anger shape our lives, cause extreme suffering, and hopefully lead to a better understanding of who we are. Such statements may be recognized as mostly belonging to Eastern philosophies, while they are of course perfectly verifiable in literature as well as in our everyday existence, without having made their way clearly enough into collective subconscious. Yet these topics have been present in Divakaruni's writing since her first collection of stories, Arranged Marriage (1995), albeit in a more "down to earth" manner.

Through her observation of human tendencies in a setting that has been remembered for millennia, the author obviously wishes to underscore how they continue to challenge human minds and behaviors. More specifically, while the Mahäbhärata remains for the Westerners a complicated mythical story, Divakaruni's five hundred pages of The Palace of Illusions make the old myth more understandable at a rather unexpected level, with Panchaali's quest for the meaning of life that addresses our own doubts, fears, and hopes of renewal and love in a world at the end of an old cycle and at the beginning of a new era. Yet, it is Panchaali's wounded pride in the first place that is the cause of a major catastrophe, the battle at Kurukshetra that will deprive her of her brother, her father and her five sons. But is the prophecy avoidable, and could Panchaali, such as we know her from the legend, have transformed herself so as to prevent the carnage? In her interaction with Krishna, god and man, and truly a guide and a friend, she learns that "wrongdoing in spite of good intentions" is the consequence of "anger and desire, our two direct enemies" (Divakaruni 2008b, 264). Was her stubbornness born out of her understanding that her husbands, who indeed loved her, cherished even more "[t]heir notion of honour, of loyalty toward each other, 
of reputation," which was more important than "[her] suffering" (2008b, 195)? How long does it take Panchaali (and the readers with her) to grasp that in a devastating war, everybody loses and nobody wins? This is exactly what Divakaruni stated in her AtGoogle appearance (March 11, 2009).

In the end, Panchaali as seen by Divakaruni manages to understand the issue: being different from men (as Panchaali finally becomes a true subject in the novel), she accepted many ordeals that proved her loyalty to her husbands and to the system that decided the course of her life. On the battlefield of Kurukshetra, she sees what she needs to learn, a true ethical notion that "the desire for vengeance" should not be "stronger than the longing to be loved" $(2008 \mathrm{~b}, 194)$.

Later, as she follows her husbands on their way to death, in the Himalayas, even this longing subsides as the major breakthrough occurs at her passing. With the help of Krishna, who manifests himself at her side, she finally opens herself to the true nature of love, totally different from the nostalgia she had experienced in the past $(2008 \mathrm{~b}, 356)$. She realizes that the same love pushed her into existence when it was her turn during her childhood to step out of the fire and into the earthly existence $(2008 \mathrm{~b}, 357)$. She finally sees that from a vast, cosmic perspective, her fate was that of "the instrument" $(2008 \mathrm{~b}, 357)$ beyond which there were other doers, other forces at work. So she is not to be blamed for the fact she forgot the origins of her being and that she caused pain and devastation (2008b, 358). When she slips into the space beyond earthly existence, "something breaks," with "a chain that was tied to the woman-shape crumpled on the snow below." She is "buoyant and expansive and uncontainable" - and she sees who she is "beyond name and gender and the imprisoning patterns of ego" - and yet "for the first time, I am truly Panchaali" (2008b, 360).

This is how Divakaruni's literature helps us to fathom the nature of human existence, assisting us to overcome the fear of death, together with all the fears that have been generated by the latter. The writer also puts forth, for our deepest cogitation, the desires we allow to rise in ourselves, in an attempt to overcome our own fears as we fight against other human beings with force and power. At the same time, she also insists that a woman's perspective on these issues is very important at this time and in this particular (global) space, when we need to reshape and envision our personal and collective future.

This is where Divakaruni's contribution to the rewriting of the Mahābhärata seems most original and powerful: in the old epic, the climax, from the Hinduist 
point of view, seems to lie in the crucial moment on the Kurukshetra battlefield, when Krishna as Arjuna's charioteer freezes the moment and allows the hero to understand the world and its laws beyond the tangible reality. The total illumination in the Bhagavad-Gita at the center of the Mahābhārata that has marked Indian thinking and living for ages could certainly not be reproduced in Divakaruni's narrative. The major reason resides in Panchaali's position at the battlefield as an observer, but may also be found in the general influence of the Bhagavad-Gìta on Indian philosophy that could not be easily dealt with in a contemporary novel. As we have seen, Divakaruni nevertheless assigns Krishna a major role in Panchaali's life and especially during her passing. The revelation that comes to Panchaali in the end, that of peace and love, with all conflicts gone, makes her understand the before and the after, together with the nature of the cosmic fire of transformation through which she was pushed into earthly existence.

When teaching The Palace of Illusions or The Mistress of Spices in a graduate critical theory seminar, one should be reminded that the worldview such as grounded in Hinduist tradition will continue to be a difficult riddle to the large majority of Western students. Even with the help of Luce Irigaray's Between East and West (Irigaray 2002), one of the rare attempts in Western philosophy to bridge the many gaps between the basic values promoted in various areas of the world, the initial cultural differences, and thus limitations, are not easily uprooted, although they may be partly overcome. Divakaruni's novels nevertheless offer new generations of potential literary scholars some material on which to dwell for years to come. In this regard, Divakaruni's novels may in time bring about a wider perspective on literature and life.

When speaking of Divakaruni's recent contributions to the most necessary transformation of our collective conscience, with the balancing of the male and the female energies such as observed in The Mistress of Spices (1997) and most certainly in The Palace of Illusions (2008b), we cannot ignore the last in the cycle of Anand's and Nisha's "adventures," Shadowland (2009b), such as is inscribed in the three books of The Brotherhood of the Conch. This volume is a "children's" story only in name, deeply moving and meant for us all to consider very seriously. The first of the three novels, The Conch Bearer (2003), is set in modern Kolkata as the starting point of the "hero's quest," Shadowland - environmentally oriented and insisting on our collective responsibility for the destiny of the planet (see Divakaruni's interview at the University of Central Florida, in 2009) - brings us back to a city set in a future not so far away from today. After his attempt to heal 
the past, through dedication, courage, love and the deepest conviction that only the purest ethics may prevail in the world, the young hero Anand, together with his companion Nisha, a girl who made her way into the Brotherhood, is sent on yet another journey, into the future that is threatening the extinction of all that is dearest to this boy.

Divakaruni's foundation for the development of her ideas in this novel is not difficult to assimilate: it is the present that shapes the future, as our lives of today reflect the accumulation of our past experiences and responsibilities. Such a position is not to be linked exclusively to a writer's native background, with the basic understanding of karma as an unavoidable dimension of our lives that may be influenced and shaped appropriately if we observe our actions and choose to act ethically, also in the sense of the Yogic principles of Yamas and Niyamas. Divakaruni certainly does not "preach" any specific philosophy or even worldview; rather, as a highly aware and responsible person with a great heart and an exemplary literary gift, she understands life and draws from this understanding in bringing forth precisely those elements that will produce change in our own hearts and minds. In this regard, Chitra Divakaruni's connection to her heritage goes hand in hand with her love for all people, especially when they are caught in situations she may have imagined but which are all highly plausible or may become so in the nearest future.

Divakaruni's concern and compassion as shown in Shadowland are best perceived in the way she observes (and projects in the future) what is happening to her native country, in these times of globalization, forced industrialization and growing disparity between the rich and the extremely poor. As she chooses to tell a story, for example already in The Conch Bearer (2003), the first in the Brotherhood narrative (where Anand is a tea boy and Nisha a street-sweeper), Divakaruni is aware that it will involve her readers so that they may respond with their emotions, their memories and their intuition.

As Divakaruni creates situations that may soon befall humanity, she imagines for her young heroes all the challenges that will make them understand better who they are and what their task is, allowing them to grow responsibly, honoring Life's mysteries. She points at the separation between power-seeking science that wants to control everything and everyone, privileging the intellect and smothering the heart, and the spiritual quest, the "magic," the "tradition" that has been alive for millennia and may be eradicated in the very country in which it originated. In this world of fear-driven separation, Anand as a healer and a savior will not succeed in 
his heroic feats if he is lost in his own apprehensions, doubts and his aspiration to become recognized in his ego dimension. He needs the loving support of the feminine, the young girl Nisha, and he needs to humbly admit that no human courage and resourcefulness may bring about positive solutions without the support and protection of the "conch," the wisdom and compassion incarnate in this magical object that contains the memory of the world and the power to hold it together.

In all three novels of the Brotherhood cycle (the second, which returns to the past of Moghul domination of India, is titled The Mirror of Fire and Dreaming, 2005), the magical objects such as the conch and the mirror are metaphors for the need to acknowledge the existence of other dimensions and forces at work in the universe, but especially a call to all of us to understand that we would be lost without these dimensions - as they cannot function without our cooperationagain, without our deepest commitment to love and understanding.

In conclusion, we see that Divakaruni's literature often insists on our capability to uncover what is best in our hearts. In response to the general philosophical stance, especially among authors such as Irigaray, Divakaruni also suggests that no solutions in today's world are possible without ethics. This certainly means the concern for the good of all, of the world as a whole, and not just a portion of humanity, never just one of the opponents in a confrontation. This is particularly brought forth in The Palace of Illusions, while it has already been suggested in The Mistress of Spices and in The Brotherhood of the Conch trilogy. The characters in these novels are placed in social settings where the "supernatural" is a commonplace and a regular companion to the daily events, although the humans who hold power continue in their endeavors to bend these powers so as to use them for their personal gain. The struggle between the ego, the pride, the greed, and the need to better understand the extemporal, the all pervading, remains at the center of Divakaruni's reinterpretation of old traditions and her projection of how the future could be shaped if humankind achieved the necessary transformation toward love and understanding, as in her latest novel to date, One Amazing Thing. With her forthcoming novel Oleander Girl, anticipated to appear in 2013 and based on similar attempts to bring about understanding and reconciliation among people of all cultures, Chitra Banerjee Divakaruni may continue to inscribe herself among the prominent writers of our times who believe in the power of words to bring about change in human consciousness. 


\section{References}

Assagioli, Roberto. 1973. The Act of Will. New York: Viking Press.

Ditrich, Tamara. 2008. "Rgvedic Goddesses: Their Roles and Significance in the Vedic Pantheon.” In Indian Studies. Slovenian Contributions, edited by Lenart Škof. Calcutta, India: Sampark, 153-65.

Divakaruni, Chitra Banerjee. 1991. Black Candle: Poems about Women from India, Pakistan, and Bangladesh. Corvallis, Or: Calyx Books. [2000. Rev. ed.]

—. 1995. Arranged Marriage: Stories. New York: Anchor Books. Print.

—. 1997a. Leaving Yuba City: New and Selected Poems. New York: Anchor Books.

—. 1997b. The Mistress of Spices. New York: Anchor Books.

—. 1999. Sister of My Heart. New York [\& London]: Doubleday.

—. 2001. The Unknown Errors of Our Lives: Stories. New York: Doubleday.

—. 2002a. Neela, Victory Song. Middleton, Wis.: American Girl(r).

—. 2002b. The Vine of Desire: A Novel. New York: Doubleday.

—. 2003. The Conch Bearer: A Novel. Brookfield, Conn: Roaring Brook Press.

—. 2004. Queen of Dreams: A Novel. New York: Doubleday.

—. 2005. The Mirror of Fire and Dreaming: A Novel. New Milford, Conn: Roaring Brook Press.

—. 2008. The Palace of Illusions: A Novel. New York: Doubleday.

—. 2009a. One Amazing Thing. New York: Voice/Hyperion.

—. 2009b. Shadowland: A Novel. New York: Roaring Brook Press.

Irigaray, Luce. 2002. Between East and West: From Singularity to Community, translated by Stephen Pluháček. New York: Columbia UP.

—. 2010. "Ethical Gestures toward the Other." Poligrafi 15 (57): 3-23.

Okin, Susan Moller. 2002. “'Mistresses of Their Own Destiny”: Group Rights, Gender, and Realistic Rights of Exit." Ethics 112 (2), January: 205-30. URL:

http://www.jstor.org/stable/779593. Accessed June 21, 2010.

Rajan, Gita. 2002. “Chitra Divakaruni’s 'The Mistress of Spices': Deploying Mystical Realism.” Meridians 2 (2): 215-36. URL: http://www.jstor.org/stable/40338518. Accessed June 21, 2010.

Zupančič, Metka. 2012. "The Power of Storytelling: An Interview with Chitra Banerjee Divakaruni." Contemporary Women's Writing, July. doi: 10.1093/cww/vpr023 In print: Contemporary Women's Writing 6 (2), July: 85-101. 
Video and Internet References

American BookReview Reading Series, University of Houston-Victoria, August 30, 2007, posted September 19, 2008: Divakaruni presenting her works. Accessed June 20, 2010.http://www.youtube.com/watch? $\mathrm{v}=$ Ot3Zp3MohIo\&feature=related.

AtGoogle Talks, March 11, 2009: Divakaruni's introduction to and reading from The Palace of Illusions. Accessed June 20, 2010. http://www.youtube.com/watch?v=QPbSw5Yo2TA.

AtGoogle Talks, February 10, 2010 — "What sustains us in a time of panic? How do we survive disasters beyond our control?"-Chitra Banerjee Divakaruni presenting One Amazing Thing. Accessed June 20, 2010.

http://www.youtube.com/watch?v=pCQrufxdkHc\&NR=1.

Chitra Banerjee Divakaruni's personal site. Accessed June 20, 2010. http://www.chitradivakaruni.com/.

Interview with Chitra Banerjee Divakaruni, on BookBrowse, 2008. Accessed June 20, 2010. http://www.bookbrowse.com/author_interviews/full/index.cfm?author_number=338.

Interview with Chitra Banerjee Divakaruni, Florida Center for Literary Arts, September 9, 2009. Accessed June 20, 2010. http://www.youtube.com/watch?v=wi_-

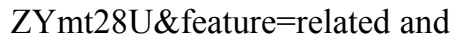
http://www.youtube.com/watch?v=PI8mvbYJj6I\&NR=1.

The Museum of Contemporary Art San Diego Presents: Divakaruni's introduction to and reading from The Mistress of Spices. Accessed June 20, 2010. http://www.youtube.com/watch?v=JAsB5tgNnNo.

UCF-Global Perspectives, May 12, 2009-“Chitra Divakaruni discusses her novel Mistress of Spices and how it reflects the culturally diverse US"-interviewer John Bersia. Accessed June 20, 2010.

http://www.youtube.com/watch?v=e11SxMycOlQ\&NR=.1. 